This PDF is a selection from a published volume from the National Bureau of Economic Research

Volume Title: The Problems of Disadvantaged Youth: An Economic Perspective

Volume Author/Editor: Jonathan Gruber, editor

Volume Publisher: University of Chicago Press

Volume ISBN: 978-0-226-30945-3

Volume URL: http://www.nber.org/books/grub07-2

Conference Date: April 13-14, 2007

Publication Date: October 2009

Chapter Title: The Behavioral Consequences of Pre-Kindergarten Participation for Disadvantaged Youth

Chapter Author: David Figlio, Jeffrey Roth

Chapter URL: http://www.nber.org/chapters/c0581

Chapter pages in book: (p. 15 - 42) 


\title{
The Behavioral Consequences of Pre-Kindergarten Participation for Disadvantaged Youth
}

\author{
David Figlio and Jeffrey Roth
}

\subsection{Introduction}

Expanding access to pre-kindergarten for disadvantaged children has been widely advocated and hotly debated in recent years, and numerous state and local jurisdictions have introduced policies to offer pre-kindergarten to these populations. While the efficacy of Head Start and pre-kindergarten programs has been studied extensively, the focus of this line of research has been nearly exclusively on school readiness and student cognitive performance, with mixed evidence to date. The most compelling of these studies exploit cross-sibling comparisons (Currie and Thomas 2000; Garces, Thomas, and Currie 2002) and regression-discontinuity designs that take advantage of variation in Head Start funding rates (Ludwig and Miller 2007). These studies find general evidence that Head Start participation has long-term benefits in terms of schooling outcomes.

But from the inception of federal support to extend educational opportunity to three- and four-year-old low-income children, there has been a consistent dual emphasis on cognitive and social development. To the plan-

David Figlio is the Orrington Lunt Professor of Education and Social Policy, and a Faculty fellow of the Institute for Policy Research, Northwestern University, and a research associate of the National Bureau of Economic Research. Jeffrey Roth is an associate professor of pediatrics in the College of Medicine at the University of Florida.

This research was funded by the Annie E. Casey Foundation, the U.S. Department of Education, and the National Science Foundation. We thank them for their support but acknowledge that the findings and conclusions presented in this report are those of the authors alone, and do not necessarily reflect the opinions of the research funders. The authors are grateful to the Florida Departments of Education and Health for the individual-level data used in this analysis. They appreciate the helpful comments of Liz Cascio, Jens Ludwig, Jon Gruber, and participants at the NBER preconference and conference on the economics of disadvantaged youth as well as those at the 2006 APPAM conference. We are responsible for any remaining errors. 
ners of Head Start in 1964, preparing disadvantaged youth to succeed in school required a "whole child" approach, one in which not only academic knowledge but also behavioral competence would be emphasized (Zigler and Styfco 2004). In addition to Head Start, the federal government also began to aid state efforts to provide local community-sponsored preschools through the mechanism of the Child Care and Development Block Grant program. This flow-through program subsidized child care programs whose quality standards were allowed to vary a great deal more than Head Start's. To supporters of Head Start, these state-subsidized early childhood programs "do not pretend to have anything to do with school readiness. They are essentially custodial programs whose only purpose is to enable poor parents to enter the work force" (Zigler and Styfco 2004, 53).

This issue - that preschool separates parents from children during crucial years of their development as a result of either an elective or required return to the workforce-remains at the heart of the debate over its potentially zero-sum benefit/harm ratio. Disadvantaged children may receive sufficient academic stimulation to compensate for missing or insufficient parental instruction, yet this cognitive benefit may be offset by two negatives: (a) low income children congregate in poor quality child care settings where unfamiliarity with appropriate social interaction is mutually reinforced; and (b) initiation into socially acceptable norms of behavior is conducted not consistently by family members but intermittently by a stranger. The preferred alternative outcome of preschool for disadvantaged youth is that it teaches school acculturation behavior in ways that improve student academic and behavioral outcomes once at school.

This chapter represents an attempt to systematically study the effects of pre-kindergarten participation on student behavior. We utilize a unique longitudinal data set that links student birth records to pre-kindergarten participation for every child born in Florida in or after 1994 who subsequently attended public school in Florida. Because pre-kindergarten participation is endogenous, we employ a novel identification strategy to estimate the effects of pre-kindergarten participation by comparing siblings within the same family. Families' access to pre-kindergarten can change over time as schools add or drop programs. We demonstrate that, within a family, the sibling with less costly access to public pre-kindergarten - measured by the fact that his or her locally-zoned elementary school offers a pre-kindergarten program when he or she is four years old - is considerably more likely to attend than the equally-eligible sibling who would have attended pre-kindergarten at a school other than his or her zoned elementary school, and use this differential access within a family as an instrument to predict public prekindergarten attendance. Using these differences in access within a family, we find that public pre-kindergarten participation apparently reduces behavioral problems in elementary school, especially when the child grows up in a particularly disadvantaged neighborhood. 


\subsection{Background}

Research suggesting the possibly negative impact of preschool participation on children's subsequent elementary school behavior is embedded in the larger debate about the psychological consequences of children of any income level being separated from their parents in the first years of life. In the early 1980s educational psychologists began employing attachment theory (Bowlby 1973; Ainsworth et al. 1978) in their study of increasing numbers of infants and toddlers being placed in public or private child care as a result of mothers rapidly returning to the workforce. Attachment theory posited that for humans to become trusting and caring individuals they must, as infants, bond with their mothers in the first year of life. The theory predicted that disruption of this attachment process (primarily to a nurturant female) would result in a child who is unable to develop self control or form stable relationships. Jay Belsky was one of the first educational psychologists to claim to have found evidence confirming this prediction. Starting in the mid 1980s, Belsky issued a series of warnings $(1986,1988,1990)$ that "early and extensive nonmaternal care carried risks in terms of increasing the probability of insecure infant-parent attachment relationships and promoting aggression and noncompliance during the toddler, preschool, and early primary school years" (Belsky 2002, 167). The research that Belsky cited was criticized on the grounds that it did not take into account the quality of the child care setting or the background characteristics of the children.

The decade of the 1990s saw a two-prong response to anxiety among both poor and nonpoor families that leaving their infants and toddlers in a group child care setting might promote adverse behavioral outcomes such as noncompliance and aggression. In the legislative arena, the National School Readiness Task Force issued a report in 1991 affirming that school readiness involved not only academic knowledge but also social competence. In 1994, Congress set school readiness to be first among the nation's eight education goals. By the year 2000, all children would have access to high-quality, developmentally appropriate preschool programs and would arrive at school able to "to maintain the mental alertness necessary" to learn (Public Law 103-227).

In the research arena, the National Institute of Child Health and Human Development (NICHD) commissioned a multicenter study of early child care and youth development. Since 1993, the NICHD Early Child Care Research Network has produced over sixty publications, many of which reach conflicting conclusions about the relationship between early child care and socioemotional development. Since the early 1990s, a great deal of research has been conducted on short- and long-run effects of children's early preschool experiences. Given that early childhood education represents a nexus of psychological theory, employment exigency, and cultural 
transmission, it is not surprising that findings in this body of research using nationally representative samples are decidedly mixed:

- The National Institute of Child Health and Human Development (NICHD) Study of Early Child Care and Youth Development (1998a) found no difference in problem behavior during the first three years among children reared exclusively at home and those who spent more than thirty hours per week in nonparental care.

- The NICHD Study of Early Child Care and Youth Development (1998b) found that mothering was a stronger and more consistent predictor of child outcomes than child care. There was little evidence that early, extensive, and continuous care was related to problematic child behavior. Child care quality was the most consistent predictor of child functioning.

- The NICHD Study of Early Child Care and Youth Development (2001) found that when quality and quantity of child care were controlled, the association between family factors and children's social-emotional development remained significant, thereby affirming that parents continue to have a meaningful effect on children's behavior despite considerable child care experience in the earliest years.

- The NICHD Study of Early Child Care and Youth Development (2003) found that children spending longer hours or more months in center care each year exhibit elevated levels of aggression and less effective impulse control.

- The national evaluation of Early Head Start (Love et al. 2005) found that children randomly assigned to the program (compared to a control group that could access any community service except Early Head Start) showed fewer problem behaviors and lower levels of aggressive behavior at twenty-four and thirty-six months. No evidence was found that more time in child care was associated with higher rates of aggressive behavior.

- First year findings from the Head Start Impact Study (U.S. Department of Health and Human Services 2005) reported effect sizes of -0.13 for total behavior problems and -0.16 for hyperactivity as reported by parents whose children were randomly assigned to Head Start. Control groups could enroll in available community non-Head Start services.

- A study of subsidized child care in Quebec found evidence of negative effects on a wide spectrum of child behavioral outcomes: hyperactivityinattention, general anxiety, separation anxiety, and physical aggressiveness/opposition (Baker, Gruber, and Milligan 2005).

- Summarizing effect sizes, the NICHD Study of Early Child Care and Youth Development (2006) concluded that more child care hours predicted more behavior problems and conflict, according to care providers. 
- Using Early Childhood Longitudinal Study data, Loeb et al. (2007) found that center-based care had a negative effect on sociobehavioral measures (with the exception of English proficient Hispanic children). Across the family income distribution, the younger the start age, the larger the negative effect. Intensity effects (more hours per day lead to more kindergarten teacher-report behavioral effects - measures of self control, interpersonal skills, and externalizing behavior) are moderated by family income and race.

- Also using Early Childhood Longitudinal Study, Magnuson, Ruhm, and Waldfogel (2007) found that participation in pre-kindergarten was associated with higher levels of behavior problems noted in the spring of first grade. This adverse relationship was somewhat attenuated for public school-located pre-kindergarten, particularly for students who continued to kindergarten in the same public school where they attended pre-kindergarten.

Parallel to the legislative and research activity at the national level, the decade of the 1990s saw states acting to extend pre-kindergarten into their K-20 educational framework. In Florida as in other states, this downward extension of public schooling to include three- and four-year-olds was partly to accommodate provisions of the Individuals with Disabilities Education Act (Public Law 99-457). Since disproportionate numbers of incoming low-income children were classified early in elementary school with special education exceptionalities such as speech and language impairment or emotional handicap, it was considered a worthwhile investment to provide these services in the context of a pre-kindergarten early intervention program (PKEI).

In funding the program, the Florida Legislature stipulated that priority be given to economically disadvantaged 3 - and 4 -year-old children whose family's income - up to 135 percent of the federal poverty level — made them free lunch eligible. Additional targets were children of migrant workers, children who had been abused, in foster care, prenatally exposed to drugs, and threeand four-year-olds not economically eligible who could participate with a fee adjusted for family income. Minimum operational parameters were set at six hours per day, five days per week during the school year with an option of extending services to ten hours per day year round. Public school PKEI teachers had to be certified in early childhood education; however, school districts could also choose to subcontract with community-based nonprofits such as Head Start or child care agencies to provide services to three- and four-year olds. Staff qualifications at nonpublic school providers were not as rigorous: a twelve-credit Child Development Associate credential (plus 120 hours of fieldwork) was acceptable to be a lead teacher. In either setting, the student-staff ratio was set at 10:1.

Throughout the 1990s, annual funding for PKEI hovered just under $\$ 100$ 
million with enrollment averaging between 25,000 to 35,000 children per year. By the time our data collection period ended (2003), the program had been transferred out of the Department of Education to the quasi publicquasi private Partnership for School Readiness housed directly inside the Governor's Office. It has since been transferred to the Agency for Workforce Innovation, lending partial support to Zigler and Styfco's contention that the mission of many state-supported preschool programs is primarily to serve as day care for mothers on welfare who are required to enter the workforce. ${ }^{1}$

So far we have been focusing on the potentially negative behavioral consequences of preschool participation. To look at the glass half-full, considerable evidence has been accumulated that "emotional development and academic learning are far more closely intertwined in the early years. ... Across a range of studies, the emotional, social, and behavioral competence of young children (such as higher levels of self-control and lower levels of acting out) predict their academic performance in first grade, over and above their cognitive skills and family backgrounds" (Raver and Knitzer $2002,3)$. The collocation of academic knowledge and self regulation in the brain is the basis for both conceptual and empirical support in favor of preschool education. To life span economists such as James Heckman, estimated rates of return to investment in preschool programs far exceed their opportunity costs. These returns to investment would be due in part because younger persons have a longer horizon over which to recoup the fruits of their investments. In Heckman's human capital model (2000), noncognitive skills and informal learning play important roles in lifetime earnings (see also Heckman 2006; Heckman and Rubinstein 2001; Heckman, Stixrud, and Urzua 2006). Most long-run studies that find support for investment in high quality early childhood programs (e.g., High/Scope Perry Preschool, Carolina Abecedarian Project, Chicago Child-Parent Centers) do not make the economic case that disadvantaged program participants caught up to earning levels of more advantaged age peers but rather that society saved money through lower rates of antisocial, cost-positive behavior such as juvenile arrest, welfare dependency, and adult incarceration (Schweinhart et al. 2005; Reynolds et al. 2002). Indeed, Belfield et al. (2006) argue that the long-term effects on crime account for a very large share of the dollar-value benefits of the Perry Preschool treatment. On the other hand, Duncan et al. (2007), utilizing data from six longitudinal data sets in the United States, Canada, and the United Kingdom, found very limited evidence that selfregulation skills at kindergarten had lasting import for long-term academic and behavioral success.

In the opening years of the present accountability-driven decade, early

1. Cascio (2006) shows that mothers entered the workforce as a result of increased availability of state subsidized kindergarten. 
childhood programs were not spared the press to quantify effects of participation. Head Start adopted a Child Outcomes Framework, and commissioned an impact study as did Early Head Start, both involving random assignment. Some state pre-kindergarten programs were evaluated on the basis of their graduates' performance in elementary school. It has become commonplace to find multilevel and growth curve models being used to investigate the relationship between treatment and proficiency. Calls for "analytical strategies aimed at explaining interindividual differences in intraindividual change" proliferate (Granger and Kivlighan 2003; Kaplan 2002). Adding to the need to be able to demonstrate value added results, the lingering controversy over possible detrimental behavioral effects of early nonmaternal, collective care has galvanized efforts to better measure and treat mental illness in children (Currie and Stabile, this volume).

In the forty years since the United States launched a nationwide program to extend equal opportunity to disadvantaged three- and four-year-olds, the mandate to provide instruction in both the cognitive and socioemotional domains has become subject to increased specificity. In Head Start's performance appraisal goals for 2007, "identifying behavioral problems in preschool children" is listed as a specific performance measure (U.S. Department of Health and Human Services/Administration for Children and Families/Office of Head Start 2007). A history of difficulty in adhering to the behavioral norms expected by schools is frequently used to explain students' poor academic performance (sometimes culminating in their exclusion from the testing pool). Thus, the burden on public pre-kindergarten programs to initiate students into socially acceptable forms of interaction has never been higher. Our study examines whether children who attended public school pre-kindergarten in Florida acquired a better grasp of socially acceptable behavior than their four-year-old peers who attended either a nonpublic preschool or no preschool at all.

This analysis makes several key advances over the existing literature. First, this is the first large-scale study to utilize administrative data on prekindergarten participation. This has the advantage of size: we observe the entire population of income-eligible students in the state of Florida born in or after 1989. Using administrative data also eliminates the potential for recall bias in measuring program participation; any student who participated in a public Head Start or school-based pre-kindergarten program in the state of Florida is observed in our data. Also, because we have matched child birth records, school-based pre-kindergarten participation records, and subsequent school behavior records for the entire state of Florida, we can rely on administratively-observed background factors and behavioral problems. (We measure behavioral problems by whether the child is referred for disciplinary action by their teachers.) Furthermore, our matching of birth vital records with school records allows us to compare within families, a strategy shared by Garces, Thomas, and Currie (2002). 
Second, the use of population-based data allow us to stratify the estimated effects of pre-kindergarten participation in a number of different ways. With tens of thousands of income-eligible families with multiple children, we can estimate with confidence the differential effects of prekindergarten participation within families along a variety of dimensions, including birth conditions, maternal age, and education.

Third, and most importantly, this analysis introduces a novel identification strategy. In addition to within-family comparisons, we exploit the fact that local policy conditions outside of the control of specific families generate different effective prices of attending public pre-kindergarten for different siblings. Whereas all students who meet certain family income or health criteria are eligible for public pre-kindergarten participation, not all students have the same ease of access. For around 60 percent of incomeeligible Florida students, the student's local zoned elementary school does not offer a public pre-kindergarten program. These students must in turn attend a pre-kindergarten site farther from their home, and perhaps without public transportation.

We argue that the presence of a pre-kindergarten program in the zoned elementary school should promote public pre-kindergarten participation for several reasons. One major reason is informational: parents are more likely to be aware of pre-kindergarten options when they have a child who attends a school that offers such a program, or when their neighbors have children who attend such a school. But transportation costs may also be a factor, even in cases when transportation to preschool is provided. This may be true for several reasons. Parents may not wish for their young children to be bused long distances, especially if they are alone. And it may be easier for parents to send their young children on a bus if they are accompanied by an older sibling or older neighbor whom the child knows; these are more likely to be the case if the pre-kindergarten is attached to the local zoned school. (In fact, the informational and neighbor-transportation factors are probably the strongest reasons for this increased likelihood of attending public pre-kindergarten when the locally zoned school offers the program, as first children attend pre-kindergarten at nearly the same rate as their younger siblings.) For all of these reasons, we suspect that it is the public school zone, rather than travel time and mileage, that matters most in determining whether children attend public pre-kindergarten programs.

We demonstrate that income-eligible students are highly responsive to the presence of a pre-kindergarten program at their zoned elementary school. Families with a pre-kindergarten program at their zoned elementary school are more than 60 percent more likely to send their children to a public prekindergarten program than are families without a pre-kindergarten program at their zoned school. And this pattern holds up within families as well: around 40 percent of families live in elementary school zones with a public pre-kindergarten program when one sibling is four but not when another sib- 
ling is four. This situation occurs either because the family changes residence, the zoning lines are redrawn, a school with a pre-kindergarten program dropped it, or because a school without a pre-kindergarten program added it. Regardless, within the same family, the sibling whose zoned elementary school has a pre-kindergarten program is 60 percent more likely to attend than the sibling without such a program at the zoned school. This probability holds when we exclude families who move, and look only at families with different access to public pre-kindergarten because of exogenous changes in local school policy. In this chapter we demonstrate that when one exploits within-family differences in access to pre-kindergarten, a positive estimated effect of pre-kindergarten on behavioral outcomes emerges.

\subsection{Disadvantage and Behavior}

How and why disadvantage correlates with behavior problems in school has been investigated by every social science discipline over the last fifty years in what now may seem like a quixotic quest for greater equality of opportunity. Two premises underlie myriad theoretical and empirical investigations of this relationship: first, students who misbehave are not learning; and second, the preponderance of students who misbehave are disadvantaged. Disruptive conduct is therefore problematic in both the short and long run: proximally, it obstructs acquisition of social and academic skills, and distally, it postpones mastery of situationally appropriate behavior and course content needed to exit disadvantaged circumstances.

The ongoing investigation of the association between disadvantage and misbehavior in school settings assess a multitude of levels, and, within levels, a multitude of factors that contribute to academic performance. Economists analyze noncognitive returns from investing in early intervention and familial resources (Heckman and Masterov 2007; Ram and Hou 2003); sociologists examine neighborhood effects and family structure (Duncan, Brookes-Gunn, and Klebanov 1994; Hao and Matsueda 2006); psychologists explore accumulated exposure to acute and chronic stressors such as perinatal complications, reduced access to healthcare, harsh and inconsistent parenting (McLoyd 1998; Barbarin et al. 2006); educators consider childcare quality, teacher expectations, and classification schemes entailed by high stakes testing (Berliner 2006; Bradley and Corwin 2002; NICHD 2005). While there have been efforts to organize these multiple levels and factors into overarching nested frameworks (see e.g., Aber, Jones, and Raver 2007), two issues remain unresolved: (a) the etiology of misbehavior (family-mediated or community-influenced); and (b) the circularity between disadvantage, behavior problems, and academic development. Since poor children arrive at school less ready to learn, they are more likely to exhibit frustration and diminished self-esteem, thereby increasing the probability of their becoming disruptive, noncompliant, overactive, and inatten- 
tive, which in turn exacerbates existing learning difficulties (Arnold and Doctoroff 2003).

A critique leveled at material deprivation models is that exogenous factors such as intelligence may be the cause of both family poverty and children's behavior and learning problems, and that such models erroneously ascribe patterns of association to income rather than to omitted variables (Mayer 1997). Contemporary interdisciplinary research uses mixed models to decompose the simultaneous deleterious effects of economic disadvantage on socioemotional competence and cognitive skills. However, the efficacy of public pre-kindergarten programs to mitigate the negative effects of material disadvantage has not been unambiguously demonstrated in these multilevel models.

A fundamental first step in any study of the relationship between disadvantage and behavior is to measure the degree to which disadvantaged students, measured along a number of dimensions, tend to misbehave at greater rates in school. Table 1.1 presents some basic facts about the rates of disciplinary problems in the first three years of school (typically, kinder-

Rates of disciplinary problems, by measure of student disadvantage

\begin{tabular}{|c|c|c|c|}
\hline & \multicolumn{3}{|c|}{ Year in school } \\
\hline & First (kindergarten) & Second & Third \\
\hline \multicolumn{4}{|c|}{ Individual measures of disadvantage } \\
\hline Teenage mothers & 0.043 & 0.065 & 0.084 \\
\hline Not teenage mother & 0.033 & 0.049 & 0.070 \\
\hline Mother has less than high school degree & 0.040 & 0.060 & 0.084 \\
\hline Mother has high school degree or greater & 0.032 & 0.046 & 0.063 \\
\hline Mother is black & 0.043 & 0.065 & 0.092 \\
\hline Mother is white & 0.035 & 0.044 & 0.051 \\
\hline Parents were unmarried at time of birth & 0.040 & 0.060 & 0.085 \\
\hline Parents were married at time of birth & 0.027 & 0.038 & 0.048 \\
\hline Child had inadequate prenatal care & 0.044 & 0.061 & 0.090 \\
\hline Child had adequate prenatal care & 0.035 & 0.053 & 0.073 \\
\hline \multicolumn{4}{|c|}{ Neighborhood measures of disadvantage } \\
\hline Above-median rate of free lunch eligibility & 0.034 & 0.056 & 0.084 \\
\hline Below-median rate of free lunch eligibility & 0.039 & 0.050 & 0.060 \\
\hline $\begin{array}{l}\text { Above-median percent nongraduate } \\
\text { mothers }\end{array}$ & 0.035 & 0.059 & 0.086 \\
\hline Below-median percent nongraduate mothers & 0.037 & 0.048 & 0.063 \\
\hline
\end{tabular}

Notes: Disciplinary problems are defined as having been referred to the principal's office for disciplinary reasons at least once during the year. To be included in the analysis, students must be in families with at least two children who were born after 1989 and enrolled in school before 2002, and where all children in the family are recorded as being eligible to receive free lunch (i.e., self-reported income less than 130 percent of the poverty line) in every observed period in school. Families are defined as two or more children who share the same birth mother. Analysis sample: 59,418 children in 29,087 families. 
garten through second grade, though we measure the year the child is in school rather than the grade) in the income-eligible population. We compare children who are considered to be disadvantaged along some individual dimension (having a teenage mother; having a mother with less than a high school diploma; having a black mother; having unmarried parents; or having inadequate prenatal care $^{2}$ ) or neighborhood dimension (living in a neighborhood with above-median rates of free lunch eligibility or non-high schoolgraduate mothers) to those not considered to be disadvantaged along that same dimension. In table 1.1 and throughout the analysis, we restrict our attention to students who are income-eligible for pre-kindergarten programs at the time of potential enrollment in pre-kindergarten. We do not actually measure income eligibility with certainty; to be income-eligible; a family must have income below 100 percent of the poverty line. However, we only observe free lunch eligibility - less than 130 percent of the federal poverty level. We therefore restrict our analysis to the set of families where all students are consistently observed being eligible for free lunch in every potential time period - about 60 percent of the students who are free lunch eligible at any given time. We expect this more restrictive measure of income eligibility to nearly approximate the true eligible population. Our analysis sample consists of 59,418 children in 29,087 families where all students in the family are consistently observed to be free lunch eligible.

We find consistent evidence that relatively disadvantaged low-income children misbehave at a greater rate than do relatively advantaged low-income children, and that this absolute gap increases over time. For instance, in the first year of school, 4 percent of children born to low-income mothers with less than a high school degree have had serious disciplinary problems, as compared with 3.2 percent of children with low-income high school graduate mothers. By the third year of school, the rate differential between the two groups increases from 0.8 percentage points to 2.3 percentage points.

Our study question of interest is whether pre-kindergarten participants misbehave at greater rates than do eligible nonparticipants. Note that we cannot directly observe private pre-kindergarten (or community-based Head Start) participation, and therefore are comparing public pre-kindergarten attendees with all other income-eligible students. Table 1.2 compares the rates of disciplinary problems in school for income-eligible children who participated in pre-kindergarten programs to those of income-eligible nonparticipating children.

One observes in table 1.2 that students who attended public prekindergarten have slightly higher rates of disciplinary problems than students who did not attend public pre-kindergarten in their early years of school. One further observes that the same patterns hold up within fami-

2. We measure inadequate prenatal care according to the Kotelchuck index that relates the number of prenatal visits to gestational age of the child. 
Table 1.2

Rates of disciplinary problems, by pre-kindergarten participation

\begin{tabular}{lccc}
\hline & \multicolumn{3}{c}{ Year in school } \\
\cline { 2 - 4 } & First (kindergarten) & Second & Third \\
\hline Nonparticipants & 0.036 & 0.050 & 0.073 \\
Pre-kindergarten participants & 0.037 & 0.058 & 0.075 \\
& Within-family comparisons & & \\
Nonparticipants & 0.035 & 0.052 & 0.075 \\
Pre-kindergarten participants & 0.035 & 0.054 & 0.077 \\
\hline
\end{tabular}

Notes: Disciplinary problems are defined as having been referred to the principal's office for disciplinary reasons at least once during the year. To be included in the analysis, students must be in families with at least two children who were born after 1989 and enrolled in school before 2002, and where all children in the family are recorded as being eligible to receive free lunch (i.e., self-reported income less than 130 percent of the poverty line) in every observed period in school. Families are defined as two or more children who share the same birth mother. Analysis sample: 59,418 children in 29,087 families.

lies. The finding in the raw data that public pre-kindergarten attendees are slightly more likely than nonattendees to have later discipline problems in the early grades could indicate that public pre-kindergarten is either ineffective in terms of engendering positive behavior or perhaps promotes noncompliant, acting-out behavior. But it could also indicate that students, even within a family, are negatively selected into public pre-kindergarten programs: the siblings most in need of socialization may be the ones that families choose to send to pre-kindergarten, while those who are reasonably well-socialized might not be sent. It could also be the case that families are transitioning in a manner that is unobservable to the researchers. The potential presence of endogeneity bias indicates the necessity of conducting instrumental variables regression.

\subsection{Evidence of Instrument Relevance}

As mentioned earlier, our instrumental variable is the presence of a public pre-kindergarten program in the public elementary school for which the student would be zoned at the time that he or she is four years old. Table 1.3 demonstrates that, in cross section, income-eligible children are much more likely to attend public pre-kindergarten when they have more direct access to it. Even though all students in our data set are eligible for public pre-kindergarten, typically with free transportation, the presence of a public pre-kindergarten program housed locally, in the same elementary school where older siblings and neighbors already attend, appears to have a powerful effect on public pre-kindergarten take-up. Comparing zip codes without community-based Head Start options, nearly 55 percent of income-eligible students attend public pre-kindergarten when the local zoned school offers 


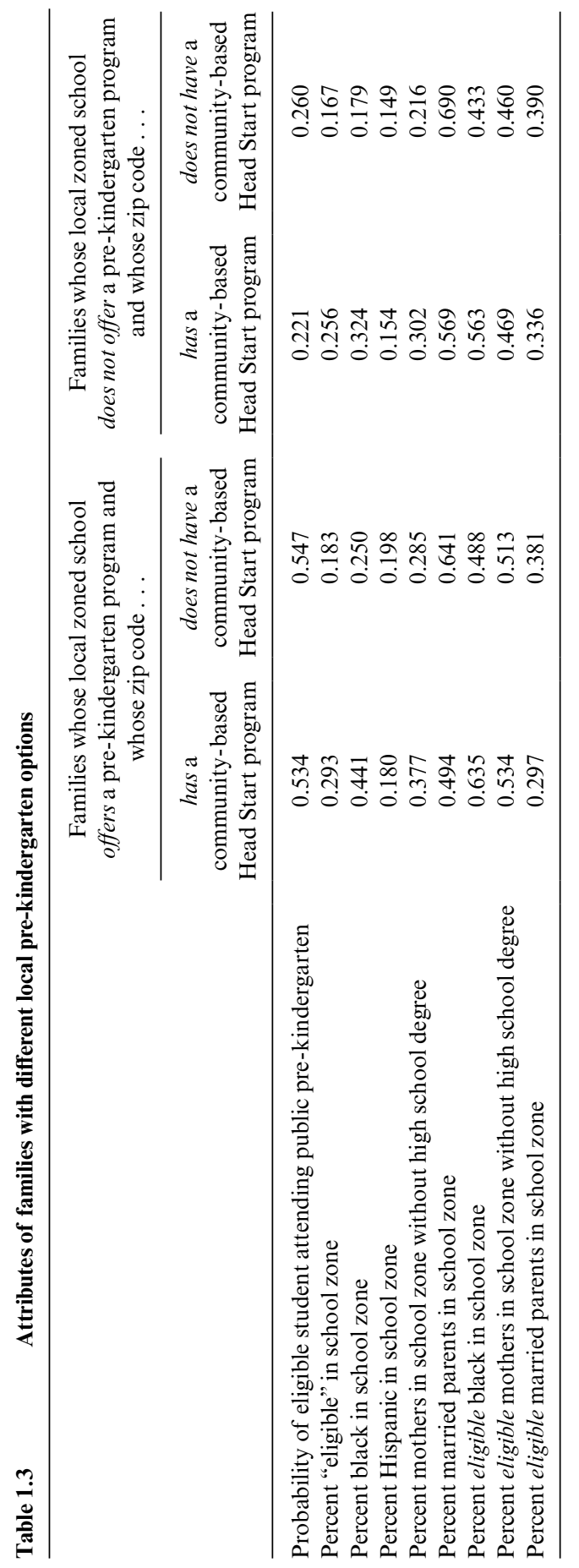


pre-kindergarten, while only 26 percent attend public pre-kindergarten when this is not the case. Note also that while the presence of a communitybased Head Start program in the zip code area slightly reduces the likelihood that a child will attend a public pre-kindergarten program ( 53 percent when the zoned school offers pre-kindergarten, and 22 percent when it does not), it is clear that the overwhelming determinant of public pre-kindergarten entry is not the community-based Head Start option, but available public pre-kindergarten access.

Table 1.3 also makes clear that a cross-sectional analysis of participation, using geographic location as an instrument, is not appropriate. This table provides basic descriptive information, culled from the full set of students whose birth records and school records are matched in Florida, on the family attributes of students across geographic locations with differing levels of access to public pre-kindergarten and community-based Head Start programs. Comparing across the columns, one observes that the school zones where public pre-kindergarten is locally offered tend to be poorer (in terms of a higher percentage "eligible" for publicly-funded pre-kindergarten ${ }^{3}$ ), with larger fractions black and Hispanic, more mothers who are not high school graduates, and fewer married parents than are the school zones where public pre-kindergarten is not locally offered. Community-based Head Start programs tend to operate in zip code areas that are poorer still, with even higher eligibility rates, more black families (though not Hispanic families), and lower rates of parental marriage and maternal high school graduation. The same patterns hold whether one looks at the attributes of the entire population of families in the school zone or whether one looks only at the attributes of income-eligible families in the school zone.

Clearly, families residing in these different types of geographical locations differ in many measured and unmeasured aspects that are independent of whether they attend public pre-kindergarten, and in fact, it makes sense that public pre-kindergarten programs (and community-based Head Start programs) would tend to locate in communities where the need for these programs is greatest. For numerous reasons, cross-sectional analysis of pre-kindergarten participation will be subject to omitted variables bias. A natural way to take into account these family-specific omitted variables is to control for family fixed effects.

An immediate problem with family fixed effects is that there are many potential reasons why one sibling might participate in pre-kindergarten while another income-eligible sibling might not. For a family fixed effects strategy to be valid, it must be the case that siblings vary according to some

3. We put the word "eligible" in quotation marks because we do not observe eligibility per se. We estimate eligibility based on the student's family's history with free lunch eligibility in the school. We are likely understating the true rate of eligibility in Florida, but this understatement does not seem important for this comparison or for the empirical analysis that follows. 
Between-family differences in pre-kindergarten attendance probabilities, by availability at zoned school

\begin{tabular}{lcc}
\hline Family type & $\begin{array}{c}\text { Number } \\
\text { of families }\end{array}$ & $\begin{array}{c}\text { Probability of attending } \\
\text { pre-kindergarten }\end{array}$ \\
\hline $\begin{array}{l}\text { No siblings' local zoned school at age four offers } \\
\text { pre-kindergarten }\end{array}$ & 11,458 & 0.346 \\
$\begin{array}{l}\text { Some, but not all, siblings' local zoned school at } \\
\text { age four offers pre-kindergarten }\end{array}$ & 12,107 & 0.425 \\
$\begin{array}{c}\text { All siblings' local zoned school at age four offers } \\
\text { pre-kindergarten }\end{array}$ & 5,522 & 0.562 \\
\hline
\end{tabular}

exogenous factor that induces one sibling to participate in the program but not the other. We contend that siblings' public pre-kindergarten take-up varies within a family based on differences in local access to pre-kindergarten; fortunately, over 40 percent of all income-eligible families with multiple children experience a change in program offerings from one sibling to the next. Table 1.4 shows that many students without a public pre-kindergarten program immediately available still go to pre-kindergarten, but the probability of attending increases dramatically if the zoned school has a program. ${ }^{4}$ Among families where the zoned school offered a pre-kindergarten program to all siblings observed in the data, 56 percent of income-eligible students attended public pre-kindergarten. On the other hand, among families for whom the zoned elementary school never offered pre-kindergarten, just 35 percent of income-eligible students attended pre-kindergarten. Table 1.5 shows again that families in the three groups presented in table 1.4 are very different, further underscoring the importance of conducting within-family comparisons.

Table 1.6 presents within-family information on public pre-kindergarten take up, by access levels. For the 12,107 "mixed" families, the sibling with the easier access to public pre-kindergarten attended these programs 52 percent of the time, while the sibling without such access attended these programs 33 percent of the time. These same differences are apparent when we compare within families of different types, stratified by maternal education, maternal age, and race. This evidence indicates that our instrumental variables strategy has a very strong and consistent (across subgroups) first stage.

4. Note that the public pre-kindergarten attendance rate is somewhat higher in the first row of table 1.4 than in the last two columns of table 1.3. This is due to differences in sample between the two tables. In table 1.3, all families, including those with just one child observed, are included, while in table 1.4, only families with two or more children observed are included. In addition, these sibling comparisons tend to be for more disadvantaged families (or families who are more consistently disadvantaged) than the potentially eligible population as a whole. 
Table 1.5

Differences in family attributes, by differences in availability at zoned school

\begin{tabular}{lccc}
\hline & $\begin{array}{c}\text { No siblings zoned } \\
\text { for a school offering } \\
\text { pre-kindergarten } \\
\text { at age four }\end{array}$ & $\begin{array}{c}\text { Somet but } \\
\text { all, siblings zoned } \\
\text { for a school offering } \\
\text { pre-kindergarten } \\
\text { at age four }\end{array}$ & $\begin{array}{c}\text { All siblings zoned } \\
\text { for a school offering } \\
\text { pre-kindergarten } \\
\text { at age four }\end{array}$ \\
\hline $\begin{array}{l}\text { Teen mother } \\
\begin{array}{l}\text { Mother with less than } \\
\text { high school education }\end{array}\end{array}$ & 0.274 & 0.259 & 0.231 \\
$\begin{array}{l}\text { Black mother } \\
\text { Mother unmarried }\end{array}$ & 0.470 & 0.514 & 0.501 \\
$\begin{array}{l}\text { Inadequate prenatal care } \\
\text { for child }\end{array}$ & 0.644 & 0.658 & 0.671 \\
\hline
\end{tabular}

Note: The attributes reported above are those in place when the youngest observed child in the family was born.

Table 1.6 Within-family differences in pre-kindergarten attendance probabilities, by availability at zoned school

\begin{tabular}{lcc}
\hline Family type & $\begin{array}{c}\text { Sibling(s) whose local } \\
\text { zoned school at age four } \\
\text { offers pre-kindergarten }\end{array}$ & $\begin{array}{c}\text { Sibling(s) whose local zoned } \\
\text { school at age four does not } \\
\text { offer pre-kindergarten }\end{array}$ \\
\hline All eligible families & 0.523 & 0.327 \\
$\begin{array}{l}\text { Mother teenaged at birth } \\
\text { Mother has less than high school } \\
\quad \text { education }\end{array}$ & 0.537 & 0.345 \\
$\begin{array}{l}\text { Mother is black } \\
\text { Mother is nonblack }\end{array}$ & 0.515 & 0.320 \\
\hline
\end{tabular}

\subsection{Regression Estimates}

Table 1.7 presents regression analysis of the estimated effects of attending public pre-kindergarten on the probability of being disciplined. Each cell in the table represents a different regression specification; the columns reflect different years in school. (Typically a student in "year 2" would be in first grade, but we chose to treat kindergarten repeaters and "natural" first graders the same way.) The regression results presented in table 1.7 include controls for school fixed effects, as well as for student race, sex, free/reduced price lunch status (though in practice, all students will show up as free lunch eligible), maternal age at birth, maternal education at birth, maternal marital status, Medicaid status at birth, adequacy of prenatal care, complications of labor and delivery, birth order, and indicators for whether the student's birth weight is less than $1,000 \mathrm{~g}, 1,000-1,500 \mathrm{~g}, 1,500-2,500 \mathrm{~g}$, or $>2,500 \mathrm{~g}$ (extremely low, very low, moderately low, or normal birth weight). The 


\begin{tabular}{lccc}
\hline Specification & $\begin{array}{c}\text { Year 1 } \\
\text { (kindergarten) }\end{array}$ & Year 2 & Year 3 \\
\hline School fixed effects & -0.000 & 0.003 & -0.004 \\
& $(0.002)$ & $(0.002)$ & $(0.003)$ \\
School and family fixed effects & 0.000 & 0.001 & 0.003 \\
& $(0.002)$ & $(0.002)$ & $(0.003)$ \\
School and family fixed effects with instrumental variable & -0.025 & -0.032 & -0.003 \\
& $(0.009)$ & $(0.011)$ & $(0.015)$ \\
School and family fixed effects with instrumental variable- & -0.020 & -0.043 & -0.009 \\
$\quad$ families with children all zoned for the same school & $(0.012)$ & $(0.015)$ & $(0.018)$ \\
Male students & -0.041 & -0.060 & -0.022 \\
& $(0.011)$ & $(0.015)$ & $(0.021)$ \\
Female students & -0.003 & 0.009 & 0.001 \\
& $(0.007)$ & $(0.010)$ & $(0.016)$ \\
School fixed effects with instrumental variable & -0.018 & -0.028 & -0.002 \\
& $(0.006)$ & $(0.010)$ & $(0.015)$ \\
\hline
\end{tabular}

Notes: Standard errors adjusted for clustering at the school level are in parentheses beneath point estimates. Each cell represents a different regression specification. Regressions also include controls for race, sex, free/reduced price lunch status, maternal age at birth, maternal marital status, maternal education levels, Medicaid status at birth, prenatal care complications of labor and delivery, indicators for birth weight $<1,000 \mathrm{~g}, 1,000-1,500 \mathrm{~g}, 1,500-2,500 \mathrm{~g},>2,500 \mathrm{~g}$, birth order and school fixed effects. The instrumental variable is an indicator for whether pre-kindergarten programs are offered at the student's zoned elementary school at age four. Disciplinary problems are defined as having been referred to the principal's office for disobeying school rules at least once during the year. To be included in the analysis, students must be in families with at least two children who were born after 1989 and enrolled in school before 2002, and where all children in the family are recorded as being eligible to receive free lunch (i.e., self-reported income less than 130 percent of the poverty line) in every observed period in school. Families are defined as two or more children who share the same birth mother. Analysis sample: 59,418 children in 29,087 families. Analysis sample for last row in table: 31,149 children in 15,248 families.

school fixed effect controls are important because schools may vary systematically in how they dispense and report discipline. As can be seen in the first row of table 1.7, one observes no apparent cross-sectional relationship between public pre-kindergarten participation and disciplinary problems in the first three years of school. The second row of the table presents the same analysis but with family fixed effects. The (non-)results remain robust; while there exist some sign changes between years, the magnitudes of the point estimates are trivial.

The third row of table 1.7 presents the instrumental variables regression results. As can be seen, there exists a negative and sizeable estimated effect of pre-kindergarten participation and behavioral problems in the first two years of school, and the estimated effect is no longer statistically significant in the third year of school. This evidence suggests that students who participated in public pre-kindergarten programs are less likely to be referred for disciplinary problems later than are nonparticipants. This result is at odds with much of the existing cross-sectional literature that demonstrates 
a positive relationship between pre-kindergarten participation and subsequent misbehavior.

However, there is reason to be skeptical of this finding. Our sample of within-family access changers consists of families who moved, families who did not move but who were rezoned from one school to another, where one school offers a pre-kindergarten program and the other does not, and families who did not move and were not rezoned, but the zoned school changed its pre-kindergarten offerings between siblings. The second source of variation - rezonings - is arguably the most exogenous source of variation, but fewer than 1 percent of these families changed access status as a consequence of rezoning. However, 45 percent of families did not move and were not rezoned, but had their access status change when their zoned elementary school either added or dropped its pre-kindergarten program. These students provide more plausible variation, and the fourth row of table 1.7 restricts the analysis to this set of students. We observe similar findings when we exclude students who changed access status because they changed residences, suggesting that endogenous location choice is not driving our within-family estimates. The fifth and sixth rows of table 1.7 stratify these findings by student sex: unsurprisingly, the results are concentrated exclusively in the male students, who are by far more likely to commit disciplinary infractions in the elementary grades.

While we believe that the within-family identification strategy is more credible than an identification strategy that exploits school changes in public pre-kindergarten offerings over time, because of the nonrandomness inherent in schools' and school districts' decisions to initiate or disband schoolbased pre-kindergarten programs, we are sensitive to the potential that cross-sibling spillovers may still undermine our within-family identification strategy. We suspect that the reasons that families are more likely to send their children to public pre-kindergarten programs when their local zoned elementary school offers such a program include both transportation and informational factors. In both of these cases, it may be the case that older siblings attending a public school could contribute to a younger sibling attending a public pre-kindergarten program at that same school. The potential presence of strong cross-sibling spillovers could undermine the credibility of this instrumental variable strategy. It turns out, however, that the comparisons in table 1.7 appear to be nearly independent of birth order. For instance, 51 percent of eligible first siblings attend pre-kindergarten when offered at their locally zoned elementary school, as compared with 53 percent of subsequent siblings. Therefore, the non-sibling-related factors associated with public pre-kindergarten participation at locally zoned elementary schools appear to be the dominant reasons for children's attendance.

That said, the potential presence of sibling spillovers driving our results remains. Therefore, in the last row of table 1.7 we repeat the same basic empirical strategy without the family fixed effects - in essence, exploiting 
cross-time changes in locally zoned schools' pre-kindergarten program offerings. When we do this analysis, the results are slightly smaller but broadly consistent with those found using family fixed effects, suggesting that the findings are not being driven by our decision to compare sibling pairs. In the remainder of this chapter, we will therefore continue to utilize our preferred within-family identification strategy using instrumental variables.

It is important to note that while a within-family instrumental variables strategy appears to be appropriate, a straight sibling comparison identification strategy is not. We find that models that control for family fixed effects yield results that are nearly identical to those that exclude family fixed effects - suggesting that within-family selection into pre-kindergarten programs apparently takes place. That our results differ substantially depending on whether or not one instruments for local access to pre-kindergarten programs indicates that researchers should exercise considerable caution when making cross-sibling comparisons.

Are these results evidence of a short-term benefit only of public prekindergarten participation? It may be the case that the absence of behavioral problems in the first two years of schooling puts a child on a different trajectory. Table 1.8 shows that students who had behavioral problems in kindergarten were much more likely to be classified as emotionally disabled or severely emotionally disturbed later on. Table 1.9 also presents instrumental variables regression analysis to show that public pre-kindergarten participation reduces the likelihood that a student, all else equal, will be classified as emotionally disabled in year two or year three of school. In fact, we observe this reduction even when we control also for a student's actual observed behavior. This finding suggests that public pre-kindergarten participation not only appears to reduce the degree of problem behavior, relative to the alternative of private preschool or no preschool for disadvantaged youth, but it also seems to further reduce the likelihood of later classification into special education classes for students with serious socialemotional handicaps - above and beyond the degree of behavioral problems observed.

Table 1.8

Relationship between disciplinary problems and subsequent classification of emotional disability

\begin{tabular}{|c|c|c|c|}
\hline & $\begin{array}{c}\text { Year 1 } \\
\text { (kindergarten) }\end{array}$ & Year 2 & Year 3 \\
\hline \multicolumn{4}{|c|}{ Probability of being classified as emotionally disabled or severely emotionally disturbed } \\
\hline Students who were referred in kindergarten & 0.016 & 0.025 & 0.026 \\
\hline Students not referred in kindergarten & 0.001 & 0.001 & 0.002 \\
\hline \multicolumn{4}{|c|}{ Probability of being classified with any disability } \\
\hline Students who were referred in kindergarten & 0.049 & 0.064 & 0.056 \\
\hline Students not referred in kindergarten & 0.025 & 0.028 & 0.031 \\
\hline
\end{tabular}


Table 1.9

Estimated effects of attending pre-kindergarten on probability of being classified as emotionally disabled or severely emotionally disturbed: Instrumental variables regression with family fixed effects

\begin{tabular}{lccc}
\hline Specification & $\begin{array}{c}\text { Year 1 } \\
\text { (kindergarten) }\end{array}$ & Year 2 & Year 3 \\
\hline Probability of being classified as emotionally disabled & -0.003 & -0.020 & -0.011 \\
$\quad \begin{array}{l}\text { or severely emotionally disturbed } \\
\text { Probability of being classified, conditional on actual } \\
\text { observed behavior }\end{array}$ & $-0.001)$ & $(0.003)$ & $(0.004)$ \\
& $(0.001)$ & -0.019 & -0.013 \\
& & $(0.003)$ & $(0.005)$ \\
\hline
\end{tabular}

Notes: Standard errors adjusted for clustering at the school level are in parentheses beneath point estimates. Each cell represents a different regression specification. Regressions also include controls for race, sex, free/reduced price lunch status, maternal age at birth, maternal marital status, maternal education levels, Medicaid status at birth, prenatal care complications of labor and delivery, indicators for birth weight $<1,000 \mathrm{~g}, 1,000-1,500 \mathrm{~g}, 1,500-2,500 \mathrm{~g}$, $>$ $2,500 \mathrm{~g}$, birth order, and school and family fixed effects. The instrumental variable is an indicator for whether pre-kindergarten programs are offered at the student's zoned elementary school at age four. Disciplinary problems are defined as having been referred to the principal's office for disobeying school rules at least once during the year. To be included in the analysis, students must be in families with at least two children who were born after 1989 and enrolled in school before 2002, and where all children in the family are recorded as being eligible to receive free lunch (i.e., self-reported income less than 130 percent of the poverty line) in every observed period in school. Families are defined as two or more children who share the same birth mother. Analysis sample: 59,418 children in 29,087 families.

\subsubsection{Falsification Exercise}

Especially given the fact that the estimated effects of public prekindergarten are considerably different depending on whether or not we instrument for pre-kindergarten participation, one might be concerned that our instrumental variables findings are being driven by the identification strategy employed. We therefore propose a falsification exercise, in which we utilize an indicator for low birth weight (i.e., less than 2,500 $\mathrm{g}$ at birth) as our replacement dependent variable. Pre-kindergarten participation cannot influence low birth weight, but an unmeasured third variable (e.g., exposure to an environmental toxin) could be associated with birth weight, pre-kindergarten participation, and behavioral outcomes. Medical research indicates that low birth weight infants have a higher incidence of behavioral problems (Johnson 2007), so this association could be seen as a strong falsification test in the event of a finding of zero effect. Therefore, in table 1.10 we conduct this falsification test. Because birth weight is a covariate in our regular regression models, we estimate this model without any covariates except for school and family fixed effects. In order to make our comparisons consistent, we also repeat our instrumental variables regression with discipline as a dependent variable to make certain that differential treatment of covariates is not responsible for the differences in results. We conduct these 
Falsification exercise: Instrumental variables evidence on low birth weight

\begin{tabular}{|c|c|c|c|c|}
\hline & $\begin{array}{l}\text { Discipline } \\
\text { in year } 1 \\
\text { (kindergarten) }\end{array}$ & $\begin{array}{l}\text { Discipline } \\
\text { in year } 2\end{array}$ & $\begin{array}{l}\text { Discipline } \\
\text { in year } 3\end{array}$ & $\begin{array}{l}\text { Low birth } \\
\text { weight }\end{array}$ \\
\hline $\begin{array}{l}\text { School and family fixed effects with instrumental } \\
\text { variable }\end{array}$ & $\begin{array}{c}-0.033 \\
(0.009)\end{array}$ & $\begin{array}{c}-0.026 \\
(0.011)\end{array}$ & $\begin{array}{l}-0.002 \\
(0.014)\end{array}$ & $\begin{array}{c}0.005 \\
(0.012)\end{array}$ \\
\hline $\begin{array}{l}\text { School and family fixed effects with instrumental } \\
\text { variable-families with children all zoned for } \\
\text { the same school }\end{array}$ & $\begin{array}{l}-0.020 \\
(0.012)\end{array}$ & $\begin{array}{c}-0.048 \\
(0.016)\end{array}$ & $\begin{array}{l}-0.028 \\
(0.018)\end{array}$ & $\begin{array}{c}0.007 \\
(0.018)\end{array}$ \\
\hline
\end{tabular}

Notes: Standard errors adjusted for clustering at the school level are in parentheses beneath point estimates. Each cell represents a different regression specification. To be included in the analysis, students must be in families with at least two children who were born after 1989 and enrolled in school before 2002, and where all children in the family are recorded as being eligible to receive free lunch (i.e., self-reported income less than 130 percent of the poverty line) in every observed period in school. Families are defined as two or more children who share the same birth mother. Analysis sample: 59,418 children in 29,087 families. Analysis sample for last row in table: 31,149 children in 15,248 families.

tests both for the full sample of families and for the set of families where all observed children were zoned for the same school.

We observe that the results are quite similar with regard to discipline as a dependent variable, regardless of whether or not we include the covariates in the model. There remains the general pattern of a negative relationship between pre-kindergarten participation and discipline in the first two years of school, with less evidence of a relationship in the third year. In the falsification exercise, however, there is no evidence of a relationship between low birth weight and pre-kindergarten participation in our instrumental variables models, providing further support for our instrumental variables identification strategy. Indeed, given the positive correlation between low birth weight and behavioral problems, the positive insignificant coefficient in the low birth weight specification is reassuring.

\subsubsection{Differential Effects by Degree of Disadvantage}

Earlier in this chapter, we show that income-eligible students who are considered disadvantaged under different dimensions tend to misbehave at greater rates than do income-eligible students who are considered to be relatively advantaged. We next investigate whether we observe differential estimated effects of pre-kindergarten participation for students of different degrees of advantage. Table 1.11 presents estimated effects of prekindergarten participation for different groups of income-eligible students, over the first two years of school, along the same measures of individual disadvantage presented in table 1.1.

As can be seen in table 1.11, there does not appear to be a consistent differential relationship between measures of disadvantage and the esti- 
Table 1.11

Estimated effects of attending pre-kindergarten on probability of being disciplined, by different measures of disadvantage: Instrumental variables estimates

\begin{tabular}{lcc}
\hline Student/family attribute & Year 1 & Year 2 \\
\hline Student has teenage mother & -0.025 & -0.040 \\
& $(0.025)$ & $(0.030)$ \\
Student does not have teenage mother & -0.027 & -0.034 \\
& $(0.009)$ & $(0.012)$ \\
Mother has less than high school degree & -0.043 & -0.043 \\
& $(0.015)$ & $(0.019)$ \\
Mother has high school degree or greater & -0.014 & -0.028 \\
& $(0.010)$ & $-0.013)$ \\
Mother is black & -0.028 & $(0.015)$ \\
& $(0.011)$ & -0.018 \\
Mother is white & -0.059 & $(0.031)$ \\
& $(0.030)$ & -0.032 \\
Parents were unmarried at time of birth & -0.026 & $(0.015)$ \\
& $(0.012)$ & -0.040 \\
Parents were married at time of birth & -0.029 & $(0.017)$ \\
& $(0.013)$ & -0.068 \\
Child had inadequate prenatal care & 0.003 & $(0.043)$ \\
& $(0.039)$ & -0.032 \\
Child had adequate prenatal care & -0.029 & $(0.012)$ \\
& $(0.010)$ &
\end{tabular}

Notes: Standard errors adjusted for clustering at the school level are in parentheses beneath point estimates. Each cell represents a different regression specification. Regressions also include controls for race, sex, free/reduced price lunch status, maternal age at birth, maternal marital status, maternal education levels, Medicaid status at birth, prenatal care complications of labor and delivery, indicators for birth weight $<1,000 \mathrm{~g}, 1,000-1,500 \mathrm{~g}$, $1,500-2,500 \mathrm{~g},>2,500 \mathrm{~g}$, birth order, and school fixed effects. The instrumental variable is an indicator for whether pre-kindergarten programs are offered at the student's zoned elementary school at age four. Disciplinary problems are defined as having been referred to the principal's office for disobeying school rules at least once during the year. To be included in the analysis, students must be in families with at least two children who were born after 1989 and enrolled in school before 2002, and where all children in the family are recorded as being eligible to receive free lunch (i.e., self-reported income less than 130 percent of the poverty line) in every observed period in school. Families are defined as two or more children who share the same birth mother. Neighborhoods are designed by public school zones.

mated effects of pre-kindergarten participation. Children born to teenage mothers apparently experience the same effects of pre-kindergarten participation as those born to nonteenage mothers. The relative estimated effects of pre-kindergarten participation are unstable from year to year with regard to race or adequacy of prenatal care. Only with regard to maternal education levels does a relatively clear pattern emerge, suggesting that children of less educated mothers apparently exhibit fewer disciplinary referrals associated with pre-kindergarten participation. This finding, however, should be inter- 
Table 1.12

\author{
Estimated effects of attending pre-kindergarten on probability of \\ being disciplined, by percentage eligible in the neighborhood, conditional \\ on community-based Head Start availability: Instrumental \\ variables estimates
}

\begin{tabular}{lccc}
\hline $\begin{array}{l}\text { Families residing in zip codes with } \\
\text { community-based Head Start availability }\end{array}$ & $\begin{array}{c}\text { Year 1 } \\
\text { (kindergarten) }\end{array}$ & Year 2 & Year 3 \\
\hline 10th percentile of percentage eligible & 0.025 & -0.004 & 0.021 \\
& $(0.034)$ & $(0.043)$ & $(0.053)$ \\
90th percentile of percentage eligible & -0.085 & -0.118 & -0.056 \\
& $(0.021)$ & $(0.026)$ & $(0.031)$ \\
$p$-value of difference & 0.00 & 0.00 & 0.00 \\
\hline
\end{tabular}

Notes: Standard errors adjusted for clustering at the school level are in parentheses beneath point estimates. Each cell represents a different regression specification. Regressions also include controls for race, sex, free/reduced price lunch status, maternal age at birth, maternal marital status, maternal education levels, Medicaid status at birth, prenatal care complications of labor and delivery, indicators for birth weight $<1,000 \mathrm{~g}, 1,000-1,500 \mathrm{~g}, 1,500-2,500 \mathrm{~g},>$ $2,500 \mathrm{~g}$, birth order, and school fixed effects. The instrumental variable is an indicator for whether pre-kindergarten programs are offered at the student's zoned elementary school at age four. Disciplinary problems are defined as having been referred to the principal's office for disobeying school rules at least once during the year. To be included in the analysis, students must be in families with at least two children who were born after 1989 and enrolled in school before 2002, and where all children in the family are recorded as being eligible to receive free lunch (i.e., self-reported income less than 130 percent of the poverty line) in every observed period in school. Families are defined as two or more children who share the same birth mother. Neighborhoods are designed by public school zones.

preted with caution given the relative instability of the other comparisons presented in table 1.11.

While students with different individual-level measures of disadvantage might not experience differential estimated effects of pre-kindergarten participation, it may be the case that differences are present when families are stratified on the basis of neighborhood measures of disadvantage. In an attempt to gauge the degree to which these neighborhood differences might be at work, we repeat the same analysis but compare the estimated effects of public pre-kindergarten participation for students in relatively advantaged neighborhoods to those for students in relatively disadvantaged neighborhoods. We define neighborhood advantage in two different ways-one based on the percentage of children in the neighborhood who are eligible for public pre-kindergarten and one based on the percentage of children in the neighborhood whose mothers are not high school graduates. These results, reported in the table 1.12, indicate that the estimated effects of public pre-kindergarten are very highly related to measures of neighborhood disadvantage. Neighborhoods with fewer disadvantaged families tend to have small (or opposite-signed) estimated effects of public pre-kindergarten programs, while neighborhoods with more disadvantaged families tend to have large, significant estimated effects of public pre-kindergarten 
Table 1.13

Estimated differential effects of attending pre-kindergarten on probability of being disciplined: Instrumental variables regression with school and family fixed effects

\begin{tabular}{|c|c|c|c|c|c|c|}
\hline \multirow[b]{2}{*}{$\begin{array}{l}\text { Family/student } \\
\text { attribute }\end{array}$} & \multicolumn{3}{|c|}{ Year 1 (kindergarten) } & \multicolumn{3}{|c|}{ Year 2} \\
\hline & $\begin{array}{l}\text { Below- } \\
\text { median } \\
\text { rate of } \\
\text { free-lunch } \\
\text { eligibility }\end{array}$ & $\begin{array}{l}\text { Above- } \\
\text { median } \\
\text { rate of } \\
\text { free-lunch } \\
\text { eligibility }\end{array}$ & $\begin{array}{l}p \text {-value of } \\
\text { difference }\end{array}$ & $\begin{array}{l}\text { Below- } \\
\text { median } \\
\text { rate of } \\
\text { free-lunch } \\
\text { eligibility }\end{array}$ & $\begin{array}{l}\text { Above- } \\
\text { median } \\
\text { rate of } \\
\text { free-lunch } \\
\text { eligibility }\end{array}$ & $\begin{array}{l}p \text {-value of } \\
\text { difference }\end{array}$ \\
\hline Teenage mother & $\begin{array}{c}-0.007 \\
(0.035)\end{array}$ & $\begin{array}{c}-0.044 \\
(0.024)\end{array}$ & 0.17 & $\begin{array}{c}0.007 \\
(0.043)\end{array}$ & $\begin{array}{l}-0.089 \\
(0.030)\end{array}$ & 0.04 \\
\hline $\begin{array}{l}\text { Mother's education less } \\
\text { than high school }\end{array}$ & $\begin{array}{c}-0.034 \\
(0.021)\end{array}$ & $\begin{array}{c}-0.047 \\
(0.016)\end{array}$ & 0.49 & $\begin{array}{c}0.015 \\
(0.026)\end{array}$ & $\begin{array}{c}-0.096 \\
(0.020)\end{array}$ & 0.00 \\
\hline Low birth weight & $\begin{array}{c}-0.015 \\
(0.045)\end{array}$ & $\begin{array}{l}-0.025 \\
(0.026)\end{array}$ & 0.80 & $\begin{array}{l}0.056 \\
(0.069)\end{array}$ & $\begin{array}{c}-0.035 \\
(0.032)\end{array}$ & 0.16 \\
\hline Black mother & $\begin{array}{c}-0.004 \\
(0.018)\end{array}$ & $\begin{array}{c}-0.046 \\
(0.011)\end{array}$ & 0.08 & $\begin{array}{l}0.018 \\
(0.025)\end{array}$ & $\begin{array}{l}-0.087 \\
(0.015)\end{array}$ & 0.00 \\
\hline
\end{tabular}

Notes: Standard errors adjusted for clustering at the school level are in parentheses beneath point estimates. Each cell represents a different regression specification. Regressions also include controls for race, sex, free/reduced price lunch status, maternal age at birth, maternal marital status, maternal education levels, Medicaid status at birth, prenatal care complications of labor and delivery, indicators for birth weight $<1,000 \mathrm{~g}, 1,000-1,500 \mathrm{~g}, 1,500-2,500 \mathrm{~g},>2,500 \mathrm{~g}$, birth order, and school and family fixed effects. The instrumental variable is an indicator for whether pre-kindergarten programs are offered at the student's local elementary school. Disciplinary problems are defined as having been referred to the principal's office for disobeying school rules at least once during the year. To be included in the analysis, students must be in families with at least two children who were born after 1989 and enrolled in school before 2002, and where all children in the family are recorded as being eligible to receive free lunch (i.e., self-reported income less than 130 percent of the poverty line) in every observed period in school. Families are defined as two or more children who share the same birth mother. Analysis sample: 59,418 children in 29,087 families.

programs. ${ }^{5}$ These results suggest that public pre-kindergarten programs are most helpful in the most disadvantaged neighborhoods.

We next consider the two-way interaction between individual measures of disadvantage and neighborhood measures of disadvantage. Table 1.13 stratifies the estimated effects of public pre-kindergarten based on a series of family attributes - mother's age, education level, and race and child's birth weight - and further by measured neighborhood disadvantage, proxied using the rate of free-lunch eligibility in the neighborhood. We observe relative consistency across the various strata by year 2 along a series of dimensions: we find that public pre-kindergarten is associated with increased estimated rates of behavioral problems in relatively advantaged neighborhoods and decreased estimated rates of behavioral problems in relatively disadvantaged communities. The differences between these two rates tend to be statistically significant in year 2 . While the results are rather noisy,

5. We have also stratified these neighborhoods by fraction eligible for pre-kindergarten participation and found very similar results. 
Table 1.14

Estimated effects of attending pre-kindergarten on probability of being suspended or repeating a grade by year 3 , by differing degrees of community disadvantage: Instrumental variables estimates

\begin{tabular}{lcc}
\hline & $\begin{array}{c}\text { Probability of being } \\
\text { suspended by year 3 }\end{array}$ & $\begin{array}{c}\text { Probability of repeating } \\
\text { a grade by year 3 }\end{array}$ \\
\hline Relatively advantaged neighborhoods: & 0.055 & 0.031 \\
below-median rate of free lunch eligibility & $(0.034)$ & $(0.042)$ \\
Relatively disadvantaged neighborhoods: & -0.052 & -0.036 \\
above-median rate of free lunch eligibility & $(0.019)$ & $(0.027)$ \\
$p$-value of difference & 0.00 & 0.06 \\
\hline
\end{tabular}

Notes: Standard errors adjusted for clustering at the school level are in parentheses beneath point estimates. Each cell represents a different regression specification. Regressions also include controls for race, sex, free/reduced price lunch status, maternal age at birth, maternal marital status, maternal education levels, Medicaid status at birth, prenatal care complications of labor and delivery, indicators for birth weight $<1,000 \mathrm{~g}, 1,000-1,500 \mathrm{~g}, 1,500-2,500 \mathrm{~g},>$ $2,500 \mathrm{~g}$, birth order, and school fixed effects. The instrumental variable is an indicator for whether pre-kindergarten programs are offered at the student's zoned elementary school at age four. To be included in the analysis, students must be in families with at least two children who were born after 1989 and enrolled in school before 2002, and where all children in the family are recorded as being eligible to receive free lunch (i.e., self-reported income less than 130 percent of the poverty line) in every observed period in school, and where all included students are observed through year 3 of school. Families are defined as two or more children who share the same birth mother.

nonetheless the general pattern of findings remains consistent with those already presented: the estimated beneficial effects of public pre-kindergarten programs are present in the relatively disadvantaged communities and not in the relatively advantaged communities.

\subsubsection{Other Outcomes}

We next turn to other outcomes besides basic discipline and emotionally disturbed classification. Specifically, in table 1.14 we consider the likelihood that a student will, by the end of his or her third year, either have been suspended out of school or repeated a grade. ${ }^{6}$ These arguably represent more serious behavioral outcomes than referral to the principal's office for a rule infraction.

As can be seen in table 1.14, patterns similar to disciplinary problems emerge with regard to suspension and grade repetition: students participating in public pre-kindergarten programs are estimated to be significantly more likely to be suspended than are nonparticipants in relatively advantaged communities, and are significantly less likely to be suspended than are nonparticipants in relatively disadvantaged neighborhoods. The difference between the two is statistically significantly different from zero as well. The

6. We present outcomes at the end of year 3 because grade repetition and suspension are low-probability events, particularly in the first year or two of school. 
patterns of signs are the same for grade repetition, but neither point estimate is statistically significant; the difference between the two, however, is statistically significant at the 7 percent level. These results, while suggestive, provide further evidence that there exist substantial differences in results between relatively advantaged versus relatively disadvantaged communities, most likely suggesting that the potential socializing benefits of public pre-kindergarten programs are strongest in the disadvantaged communities where socialization to institutional norms faces numerous obstacles.

\subsection{Conclusion}

We utilize a unique matched administrative data set and a novel identification strategy to study the effects of public pre-kindergarten participation on student behavioral outcomes. The analysis indicates that public pre-kindergarten leads to reduced student disciplinary problems and reduced rates of being classified emotionally disabled or severely emotionally disturbed. That said, we observe that the estimated benefit of public pre-kindergarten participation apparently depends crucially on the level of advantage of the neighborhood in which the student resides. We find that the favorable estimated effects of public pre-kindergarten programs are concentrated in the least advantaged communities.

In relatively advantaged neighborhoods, on the other hand, we do not find evidence that public pre-kindergarten programs have appreciable behavioral benefits. This may be due to differences in community institutions, neighborhood effects, or private pre-kindergarten alternatives in these more advantaged neighborhoods, or it may be that the families eligible for public prekindergarten who live in more advantaged neighborhoods tend to be more advantaged themselves than do their income-eligible counterparts in less advantaged neighborhoods. We will continue to investigate these differences in our future work.

\section{References}

Aber, J. L., S. M. Jones, and C. C. Raver. 2007. Poverty and child development: New perspectives on a defining issue. In Child development and social policy: Knowledge for action, ed. J. L. Aber, S. J. Bishop-Josef, S. M. Jones, K. T. McLearn, and D. A. Phillips, 149-66. Washington, D.C.: American Psychological Association.

Ainsworth, M. D. S., M. C. Blehar, E. Waters, and S. Wall. 1978. Patterns of attachment: A psychological study of the strange situation. Hillsdale, NJ: Erlbaum.

Arnold, D. H., and G. L. Doctoroff. 2003. The early education of socioeconomically disadvantaged children. Annual Review of Psychology 54 (January): 517-45.

Baker, M., J. Gruber, and K. Milligan. 2005. Universal childcare, maternal labor supply, and family well-being. NBER Working Paper no. 11832. Cambridge, MA: National Bureau of Economic Research, December. 
Barbarin, O., D. Bryant, T. McCandies, M. Burchinal, D. Early, R. Clifford, R. Pianta, and C. Howes. 2006. Children enrolled in public pre-K: The relation of family life, neighborhood quality, and socioeconomic resources to early competence. American Journal of Orthopsychiatry 76 (2): 265-76.

Belfield, C., M. Nores, S. Barnett, and L. Schweinhart. 2006. The High/Scope Perry preschool program: Cost-benefit analysis using data from the age-40 followup. Journal of Human Resources 41 (1): 162-90.

Belsky, J. 1986. Infant day care: A cause for concern? Zero to Three 6:1-9. 1988. The "effects" of infant day care reconsidered. Early Childhood Research Quarterly 3:235-72.

1990. Developmental risks associated with infant day care: Attachment insecurity, noncompliance, and aggression? In Psychosocial issues in day care, ed. S. Chehrazi, 37-68. Washington, D.C.: American Psychiatric Press.

. 2002. Quantity counts: Amount of child care and children's socioemotional development. Developmental and Behavioral Pediatrics 23 (3): 167-70.

Berliner, D.C. 2006. Our impoverished view of educational research. Teachers College Record 108 (6): 949-95.

Bowlby, J. 1973. Attachment and loss. New York: Basic Books.

Bradley, R. H., and R. F. Corwyn. 2002. Socioeconomic status and child development. Annual Review of Psychology 53 (February): 371-99.

Cascio, E. 2006. Do large investments in early education pay off? Long-term effects of introducing kindergartens into public schools. Dartmouth College, Working Paper.

Currie, J., and D. Thomas. 2000. School quality and the longer-term effects of Head Start. Journal of Human Resources 35 (4): 755-74.

Duncan, G. J., J. Brooks-Gunn, and P. K. Klebanov. 1994. Economic deprivation and early childhood development. Child Development 62 (2): 296-318.

Duncan, G. J., A. Claessens, A. C. Huston, L. S. Pagani, M. Engel, C. J. Dowsett, H. Sexton, et al. 2007. School readiness and later achievement. Developmental Psychology 43 (6): 1428-46.

Garces, E., D. Thomas, and J. Currie. 2002. Longer term effects of Head Start. American Economic Review 92 (4): 999-1012.

Granger, D., and K. Kivlighan. 2003. Integrating biological, behavioral, and social levels of analysis in early child development: Progress, problems, and prospects. Child Development 74 (4): 1058-63.

Hao, L., and R. L. Matsueda. 2006. Family dynamics through childhood: A sibling model of behavior problems. Social Science Research 35 (2): 500-24.

Heckman, J. 2000. Policies to foster human capital. Research in Economics 54 (1): $3-56$.

2006. Skill formation and the economics of investing in disadvantaged children. Science 312 (5782): 1900-02.

Heckman, J. J., and D. V. Masterov. 2007. The productivity argument for investing in young children. Review of Agricultural Economics 29 (3): 446-93.

Heckman, J. J., and Y. Rubinstein. 2001. The importance of noncognitive skills: Lessons from the GED testing program. American Economic Review 91 (2): $145-49$.

Heckman, J. J., J. Stixrud, and S. Urzua. 2006. The effects of cognitive and noncognitive abilities on labor market outcomes and social behavior. Journal of Labor Economics 24 (3): 411-82.

Johnson, S. 2007. Cognitive and behavioural outcomes following very preterm birth. Seminars in Fetal and Neonatal Medicine 12 (5): 363-73.

Kaplan, D. 2002. Methodological advances in the analysis of individual growth with relevance to education policy. Peabody Journal of Education 77 (1): 189-215. 
Loeb, S., M. Bridges, D. Bassok, B. Fuller, and R. Rumberger. 2007. How much is too much? The influence of preschool centers on children's social and cognitive development. Economics of Education Review 26 (1): 52-66.

Love, J., E. E. Kisker, C. Ross, J. Constantine, K. Boller, R. Chazan-Cohen, C. Brady-Smith, et al. 2005. The effectiveness of Early Head Start for 3-year-old children and their parents: Lessons for policy and programs. Developmental Psychology 41 (6): 885-901.

Ludwig, J., and D. Miller. 2007. Does Head Start improve children's life chances? Evidence from a regression-discontinuity approach. Quarterly Journal of Economics 122 (1): 158-208.

Magnuson, K. A., C. Ruhm, and J. Waldfogel. 2007. Does prekindergarten improve school preparation and performance? Economics of Education Review 26 (1): $33-51$.

Mayer, S. E. 1997. What money can't buy: Family income and children's life chances. Cambridge, MA: Harvard University Press.

McLoyd, V. C. 1998. Socioeconomic disadvantage and child development. American Psychologist 53 (2): 185-204.

National Institute of Child Health and Human Development (NICHD) Early Child Care Network. 1998a. Early child care and self-control, compliance, and problem behavior at twenty-four and thirty-six months. Child Development 69 (4): $1145-70$.

1998b. Relations between family predictors and child outcomes: Are they weaker for children in child care? Developmental Psychology 34 (5): 1119-28.

- 2001. Nonmaternal care and family factors in early development: An overview of the NICHD study of early child care. Journal of Applied Developmental Psychology 22 (4): 457-92.

2003. Does amount of time in child care predict socioemotional adjustment during the transition to kindergarten? Child Development 74 (4): 976-1005.

NICHD Early Child Care Research Network. 2005. Duration and developmental timing of poverty and children's cognitive and social development from birth through third grade. Child Development 76 (4): 795-810.

. 2006. Child-care effect sizes for the NICHD Study of Early Child Care and Youth Development. American Psychologist 61 (2): 99-116.

Ram, B., and F. Hou. 2003. Changes in family structure and child outcomes: Roles of economic and familial resources. Policy Studies Journal 31 (3): 309-30.

Raver, C. C., and J. Knitzer. 2002. Ready to enter: What research tells policymakers about strategies to promote social and emotional school readiness among threeand four-year-old children. Discussion Paper, National Center for Children in Poverty, Columbia University, Mailman School of Public Health.

Reynolds, A. J., J. A. Temple, D. L. Robertson, and E. A. Mann. 2002. Age 21 costbenefit analysis of the Title I Chicago Child-Parent Centers. Educational Evaluation and Policy Analysis 24 (4): 267-303.

Schweinhart, L. J., J. Montie, Z. Xiang, W. S. Barnett, C. R. Belfield, and M. Nores. 2005. Lifetime effects: The High/Scope Perry preschool study through age 40. Ypsilanti, MI: High/Scope Press.

U.S. Department of Health and Human Services, Administration for Children and Families. 2005. Head Start Impact Study: First year findings. Washington, D.C.: Office of Planning, Research and Evaluation.

U.S. Department of Health and Human Services. 2007. Head Start Reauthorization: Public Law 110-134.

Zigler, E., and S. Styfco. 2004. The Head Start debates. Baltimore, MD: P. H. Brookes. 